\title{
IMPLIKASI PUTUSAN MK TERHADAP STATUS HUKUM ANAK DI LUAR NIKAH
}

\author{
Abdul Halim Musthofa*
}

\section{Abstrak}

Status anak di luar nikah yang menurut undangundang hanya memiliki hubungan keperdataan dengan ibunya dan keluarga ibunya saja. Aturan tersebut dianggap tidak adil karena dibebankan kepada anak. Maka putusan MK, berdasarkan pada UUD 1945 dan perkembangan teknologi, status anak di luar nikah mendapatkan hak yang sepadan dengan anak dengan status perkawinan bagi si laki-laki. Penghapusan perlakuan diskriminatif terhadap anak luar kawin tentu akan memberikan nilai kebaikan bagi masa depan anak. Tentunya kedudukan anak di luar nikah menjadi setara dengan anak yang lahir sebagai akibat perkawinan yang sah.

\section{Kata Kunci, Status Hukum, Anak di luar Nikah}

\section{Pendahuluan}

Mahkamah Konstitusi (MK) berdasarkan Pasal $24 \mathrm{C}$ ayat (1) UUD 1945 mempunyai empat kewenangan konstitusional dan satu kewajiban konstitusional ketentuan itu kembali dipertegas dalam Pasal 10 ayat (1) huruf a sampai dengan d UU 24/2003 tentang Mahkamah Konstitusi; ${ }^{1}$ atas kewenanganya tersebut Mahkama Konstitusi Republik Indonesia kembali memberikan putusan monumental dalam ranah hukum keluarga atas permohonan pengujian Undang-undang Nomor 1 Tahun 1974 tentang Perkawinan terhadap Undang-undang Dasar Negara Republik Indonesia Tahun 1945 yang diajukan Machica Mochtar, artis yang melakukan nikah secara siri dengan (Alm)

* Institut Agama Islam Tribakti (IAIT) Kediri

1 Jenedjri M. Gaffar, Kedudukan, Tugas dan Peran Mahkamah Konstitusi Dalam Sistem Ketetanegaraan Republik Indonesia, Makalah: Surakarta, 17 Oktober 2009. 
Moerdiono mantan Mensesneg di era Presiden Soeharto. Machica mengajukan uji materi kepada Mahkamah Konstitusi agar Pasal 2 ayat (2) yang mengatur masalah pencatatan perkawinan dan Pasal 43 ayat (1) yang mengatur status keperdataan anak di luar nikah dinyatakan bertentangan dengan konstitusi dan harus dinyatakan tidak mempunyai kekuatan hukum dengan segala akibatnya.

Sebelum lahir keputusan MK yang mengatur anak di luar nikah, negara telah mewajibkan pencatatan perkawinan dengan tujuan tertib administrasi, meskipun pada tataran praktiknya masih banyak orang yang melakukan perkawinan tanpa dicatatkan di kantor urusan agama setempat dengan berbagai alasan. Karena pemenuhan persyaratan administratif perkawinan termasuk finansial masih dirasa membebani oleh sebagian orang untuk melakukan pencatatan. Belum lagi, masih banyak praktik masyarakat yang mengawinkan anaknya di bawah umur yang diperbolehkan oleh undang-undang, yaitu belum berumur 16 tahun bagi wanita dan 19 tahun bagi pria.

Selain itu, sebagaimana yang disyaratkan oleh Undangundang Perkawinan Nomor 1 Tahun 1974 Pasal 4 ayat 2 yang mengatur poligami banyak pria yang terganjal untuk melakukan pencatatan perkawinan karena ia masih terikat perkawinan dengan orang lain dan harus mendapat izin menikah terlebih dahulu dari pengadilan, padahal isteri pertama tidak menyetujui rencana suaminya untuk berpoligami serta tidak terpenuhinya syarat alternatif lain yaitu: isteri tidak dapat menjalankan kewajibannya sebagai istri. Istri mendapat cacat badan atau penyakit yang tidak dapat disembuhkan, dan isteri tidak dapat melahirkan keturunan. ${ }^{2}$ Sehingga perkawinan yang tidak dicatatkan tersebut berakibat tidak diperolehnya perlindungan hukum yang diberikan oleh negara meskipun perkawinan tersebut dipandang sah karena dilakukan sesuai ketentuan dan tata-cara agama dan kepercayaannya. Namun setelah salah satu pihak yang terikat dalam perkawinan tersebut melakukan tindakan wanprestasi maka pihak yang merasa dirugikan akan kesulitan mengajukan gugatan karena tidak mempunyai bukti akta autentik untuk membuktikan adanya ikatan perkawinan

\footnotetext{
${ }^{2}$ Undang-undang Nomor 1 Tahun 1974 tentang Perkawinan
} 
tersebut. $^{3}$

Masalah krusial lain dalam hukum keluarga adalah status hak keperdataan anak di luar nikah yang menurut undangundang hanya memiliki hubungan keperdataan dengan ibunya dan keluarga ibunya saja. Aturan tersebut dianggap tidak adil karena dibebankan kepada anak. Sebab seorang anak yang tidak berbuat dosa harus menanggung kesalahan yang diperbuat oleh orang tuanya, padahal pria yang menyebabkan kelahiran anak tersebut terbebas dari kewajiban hukum untuk memelihara, mendidik dan memberikan perlindungan yang seharusnya diberikan orang tua kepada anaknya.

Dengan melakukan pemahaman secara a contrario terhadap pengertian anak sah sebagaimana tercantum dalam Pasal 42 Undang-undang Perkawinan maka anak di luar nikah (anak tidak sah) dapat diartikan sebagai anak yang tidak dilahirkan dalam atau sebagai akibat perkawinan yang sah. Pada tataran praktik, misalnya dapat dilihat pada anak yang lahir akibat hubungan seks bebas dan pemerkosaan.

Selain peniadaan hubungan perdata anak di luar nikah dengan ayah dan keluarga ayahnya, anak di luar nikah terkadang masih mendapat stigma negatif masyarakat. Istilah "anak haram" dan lainnya yang sering disematkan sebagian orang kepada anak di luar nikah dinilai sebagai sanksi sosial tanpa dasar, meski sang anak tidak bersalah dan tidak pernah berharap dilahirkan dari orang tua yang tidak memiliki ikatan perkawinan.

\section{Pengertian Anak Di luar Nikah Menurut Undang-undang dan Hukum Islam}

Jika diteliti secara mendalam tentang anak di luar nikah meskipun dalam Kompilasi Hukum Islam tidak menentukan secara khusus dan pasti tentang pengelompokan anak, sebagaimana pengelompokan yang terdapat dalam hukum perdata umum. Dalam Kompilasi Hukum Islam selain dijelaskan tentang kriteria anak sah (yang dilahirkan dalam ikatan perkawinan yang sah), sebagaimana yang dicantumkan dalam

3 Dampak Perkawinan di Bawah Tangan Bagi Perempuan. www.lbh-apik.or.id 
Pasal 99 Kompilasi Hukum Islam, yang berbunyi bahwa anak yang sah adalah:

1. Anak yang dilahirkan dalam atau akibat perkawinan yang sah.

2. Hasil pembuahan suami isteri yang di luar rahim dan dilahirkan oleh isteri tersebut.

Juga dikenal anak yang lahir di luar perkawinan yang sah, seperti yang tercantum dalam Pasal 100 Kompilasi Hukum Islam bahwa "anak yang lahir di luar perkawinan hanya mempunyai hubungan nasab dengan ibunya dan keluarga ibunya". ${ }^{4}$ Di samping itu dijelaskan juga tentang status anak dari perkawinan seorang laki-laki dengan perempuan yang dihamilinya sebelum pernikahan. Sebagaimana yang tercantum pada Pasal 53 ayat (3) Kompilasi Hukum Islam: "Dengan dilangsungkannya perkawinan pada saat wanita hamil, tidak diperlukan perkawinan setelah anak yang dikandung lahir".

Begitu juga dalam Pasal 75 huruf (b) Kompilasi Hukum Islam juga dijelaskan tentang status anak dari perkawinan yang dibatalkan, yang berbunyi "Keputusan pembatalan perkawinan tidak berlaku surut terhadap anak-anak yang dilahirkan dari perkawinan tersebut". Sedangkan dalam Pasal 162 Kompilasi Hukum Islam dijelaskan tentang status anak li'an (sebagai akibat pengingkaran suami terhadap janin dan/atau anak yang dilahirkan isterinya).

Dengan demikian, jelas bahwa Kompilasi Hukum Islam tidak mengatur pengelompokkan dan jenis anak secara sistematis yang disusun dalam satu Bab tertentu, sebagaimana pengklasifikasian yang tercantum dalam UU Nomor 1 Tahun 1974. Dalam pasal 42 Bab IX UU Nomor 1 Tahun 1974 tersebut dijelaskan bahwa anak yang sah adalah anak yang dilahirkan dalam atau sebagai akibat perkawinan yang sah yang termasuk dalam kategori pasal ini adalah:

1. Anak yang dilahirkan oleh wanita akibat suatu ikatan perkawinan yang sah.

2. Anak yang dilahirkan oleh wanita di dalam ikatan perkawainan dengan tenggang waktu minimal 6 (enam) bulan antara peristiwa pernikahan dengan melahirkan bayi.

\footnotetext{
${ }^{4}$ Inpres Nomor 1 Tahun 1991 Tentang Kompilasi Hukum Islam
} 
3. Anak yang dilahirkan oleh wanita dalam ikatan perkawinan yang waktunya kurang dari kebiasaan masa kehamilan tetapi tidak diingkari kelahirannya oleh suami. ${ }^{5}$

Karena itu untuk mendekatkan pengertian "anak di luar nikah" akan diuraikan pendekatan berdasarkan terminologi yang tertera dalam kitab fikih, yang dipadukan dengan ketentuan yang mengatur tentang status anak yang tertera dalam pasal-pasal UU Nomor 1 Tahun 1974 dan Kompilasi Hukum Islam.

Hasanayn Muhammad Makluf membuat terminologi anak zina sebagai anak yang dilahirkan sebagai akibat dari hubungan suami isteri yang tidak sah. Hubungan suami isteri yang tidak sah sebagaimana dimaksud adalah hubungan badan (senggama/ wathi') antara dua orang yang tidak terikat tali pernikahan yang memenuhi unsur rukun dan syarat nikah yang telah ditentukan. ${ }^{6}$ Selain itu, hubungan suami isteri yang tidak sah tersebut, dapat terjadi atas dasar suka sama suka ataupun karena perkosaan, baik yang dilakukan oleh orang yang telah menikah ataupun belum menikah. Meskipun istilah "anak zina" merupakan istilah yang popular dan melekat dalam kehidupan masyarakat, namun Kompilasi Hukum Islam tidak mengadopsi istilah tersebut untuk dijadikan sebagai istilah khusus di dalamnya.

Hal tersebut bertujuan agar "anak" sebagai hasil hubungan zina, tidak dijadikan sasaran hukuman sosial, celaan masyarakat dan lain sebagainya, dengan menyandangkan dosa besar (berzina) ibu kandungnya dan ayah alami (genetik) anak tersebut kepada dirinya, sekaligus untuk menunjukan identitas Islam tidak mengenal adanya dosa warisan. Untuk lebih mendekatkan makna yang demikian maka Pasal 44 ayat (1) UU Nomor 1 Tahun 1974 hanya menyatakan "seorang suami dapat menyengkal sahnya anak yang dilahirkan oleh isterinya, bilamana ia dapat membuktikan bahwa isterinya telah berzina dan kelahiran anak itu akibat daripada perzinaan tersebut". ?

${ }^{5}$ Ali Afandi, Hukum Waris, Hukum Keluarga, Hukum Pembuktian, (Jakarta: Rienek Cipta, 2000), h. 30

${ }^{6}$ Abdul Aziz Dahlan, Ensklopedi Hukum Islam, (Jakarta: PT. Ichtiar Baru Van Hoeve, 1999), h. 40

7 J. Satrio, Hukum Keluarga Tentang Kedudukan Anak Dalam Undang-undang, (Bandung: PT. Citra Bhakti Aditya, 2000), h. 5 
Dalam Kompilasi Hukum Islam kalimat yang mempunyi makna "anak zina" sebagaimana definisi yang dikemukaan oleh Hasanayn di atas, adalah istilah "anak yang dilahirkan di luar perkawinan yang sah", sebagaimana yang terdapat pada Pasal 100 Kompilasi Hukum Islam, yang menyebutkan bahwa "anak yang lahir di luar perkawinan hanya mempunyai hubungan nasab dengan ibunya dan keluarga ibunya." Menurut Sayyid Sabiq dalam Kitab Fiqh Sunnah, anak zina adalah anak yang dilahirkan di luar perkawinan yang sah dan tidak mempunyai hubungan kewarisan dengan ayah karena tidak adanya nasab yang sah, hanya mempunyai hubungan kewarisan dengan ibunya saja. Kemudian dalam pasal 186 Kompilasi Hukum Islam disebutkan, "anak yang lahir di luar perkawinan hanya mempunyai hubungan saling mewaris dengan ibunya dan keluarga ibunya". Berdasarkan defenisi dan pendekatan makna "anak zina" di atas, maka yang dimaksudkan dengan anak zina dalam pembahasan ini adalah anak yang janin/pembuahannya merupakan akibat dari perbuatan zina, ataupun anak yang dilahirkan di luar nikah, sebagai akibat dari perbuatan zina.

Pendekatan istilah "anak zina" sebagai "anak yang lahir di luar nikah yang sah", berbeda dengan pengertian anak zina yang dikenal dalam hukum perdata umum, sebab dalam perdata umum, istilah anak zina adalah anak yang dilahirkan dari hubungan dua orang, laki-laki dan perempuan yang bukan suami isteri, di mana salah seorang atau kedua-duanya terikat satu perkawinan dengan orang lain. Karena itu anak di luar nikah yang dimaksud dalam hukum perdata adalah anak yang dibenihkan dan dilahirkan di luar nikah dan istilah lain yang tidak diartikan sebagai anak zina.

Perbedaan anak zina dengan anak di luar nikah menurut hukum perdata adalah sebagai berikut:

1. Apabila orang tua salah satu atau keduannya masih terikat dengan perkawinan lain, kemudian mereka melakukan hubungan seksual dan melahirkan anak, maka anak tersebut disebut anak zina.

2. Apabila orang tua anak di luar nikah itu masih sama-sama bujang (jejaka, perawan, duda dan janda), mereka mengadakan hubungan seksual dan melahirkan anak maka 
anak itu disebut anak di luar nikah ${ }^{8}$.

Dengan demikian sejalan dengan Pasal 43 ayat (1) UU Nomor 1 Tahun 1974 yang rumusannya sama dengan Pasal 100 KHI, adalah: "anak yang lahir di luar perkawinan hanya mempunyai hubungan nasab dengan ibunya dan keluarga ibunya". Yang termasuk anak yang lahir di luar pernikahan adalah:

1. Anak yang dilahirkan oleh wanita yang tidak mempunyai ikatan perkawinan yang sah dengan pria yang menghamilinya.

2. Anak yang dilahirkan oleh wanita akibat korban perkosaan oleh satu orang pria atau lebih.

3. Anak yang dilahirkan oleh wanita yang dili'an (diingkari) oleh suaminya.

4. Anak yang dilahirkan oleh wanita yang kehamilannya akibat salah orang (salah sangka), disangka suami ternyata bukan.

5. Anak yang dilahirkan oleh wanita yang kehamilannya akibat pernikahan yang diharamkan seperti menikah dengan saudara kandung atau saudara sepesusuan.

Angka 4 dan 5 di atas dalam hukum Islam disebut anak Subhat yang apabila diakui oleh Bapak subhatnya, nasabnya dapat dihubungkan kepadanya.

\section{Akibat Hukum Anak Di luar Nikah}

Jika seorang anak telah dihukumkan sebagai anak yang lahir di luar nikah sebagaimana diuraikan di atas, maka terdapat beberapa akibat hukum menyangkut hak dan kewajiban antara anak, ibu yang melahirkannya dan ayah/bapak alaminya (genetiknya), yaitu:

\section{Hubungan Nasab.}

Sebagaimana dijelaskan di atas tentang kedudukan anak di luar nikah dalam Pasal 100 Kompilasi Hukum Islam, bahwa anak yang lahir di luar perkawinan hanya mempunyai hubungan nasab dengan ibunya dan keluarga ibunya saja. Hal tersebut

${ }^{8}$ R Soetojo Prawirohamidjojo, Hukum Waris Kodifikasi, (Surabaya: Airlangga University Press, 2000), h. 16 
secara hukum, anak tersebut sama sekali tidak dapat dinisbahkan kepada ayah/bapak alaminya, meskipun secara nyata ayah/bapak alami (genetik) tersebut merupakan laki-laki yang menghamili wanita yang melahirkannya itu. ${ }^{9}$ Meskipun secara sekilas terlihat tidak manusiawi dan tidak berimbang antara beban yang diletakkan di pundak pihak ibu saja, tanpa menghubungkannya dengan laki-laki yang menjadi ayah genetik anak tersebut, namun ketentuan demikian dinilai menjunjung tinggi keluhuran lembaga perkawinan, sekaligus menghindari pencemaran terhadap lembaga perkawinan.

\section{Nafkah.}

Oleh karena status anak tersebut menurut hukum hanya mempunyai hubungan nasab dengan ibunya dan keluarga ibunya semata, maka yang wajib memberikan nafkah anak tersebut adalah ibunya dan keluarga ibunya saja. Sedangkan bagi ayah/bapak alami (genetik), meskipun anak tersebut secara biologis merupakan anak yang berasal dari spermanya, namun secara yuridis formal sebagaimana maksud Pasal 100 Kompilasi Hukum Islam di atas, tidak mempunyai kewajiban hukum memberikan nafkah kepada anak tersebut.

Hal tersebut berbeda dengan anak sah. Terhadap anak sah, ayah wajib memberikan nafkah dan penghidupan yang layak seperti nafkah, kesehatan, pendidikan dan lain sebagainya kepada anak-anaknya, sesuai dengan penghasilannya, sebagaimana ketentuan Pasal 80 ayat (4) Kompilasi Hukum Islam, dalam hal ayah dan ibunya masih terikat tali pernikahan. Apabila ayah dan ibu anak tersebut telah bercerai, maka ayah tetap dibebankan memberi nafkah kepada anak-anaknya, sesuai dengan kemampuannya, sebagaimana maksud Pasal 105 huruf (c) dan Pasal 156 huruf (d) Kompilasi Hukum Islam. ${ }^{10}$

Meskipun dalam kehidupan masyarakat ada juga ayah alami/genetik yang memberikan nafkah kepada anak yang demikian, maka hal tersebut pada dasarnya hanyalah bersifat manusiawi, bukan kewajiban yang dibebankan hukum

9 Abdul Kadir Muhammad, Humum Perdata di Indonesia, (Bandung: PT. Citra Aditya Bakti, 1993), h 93

${ }^{10}$ Ibid., 
sebagaimana kewajiban ayah terhadap anak sah. Oleh karena itu secara hukum anak tersebut tidak berhak menuntut nafkah dari ayah/bapak alami (genetiknya).

\section{Hak-Hak Waris.}

Sebagai akibat lanjut dari hubungan nasab seperti yang dikemukakan, maka anak tersebut hanya mempunyai hubungan waris-mewarisi dengan ibunya dan keluarga ibunya saja, sebagaimana yang ditegaskan pada Pasal 186 Kompilasi Hukum Islam: "Anak yang lahir di luar perkawinan hanya mempunyai hubungan saling mewarisi dengan ibunya dan keluarga dari pihakibunya". Dengan demikian, maka anak tersebut secara hukum tidak mempunyai hubungan hukum saling mewarisi dengan ayah/bapak alami (genetiknya).

\section{Hak Perwalian}

Apabila dalam satu kasus bahwa anak yang lahir akibat dari perbuatan zina (di luar nikah) tersebut ternyata wanita, dan setelah dewasa anak tersebut akan menikah, maka ayah/bapak alami (genetik) tersebut tidak berhak atau tidak sah untuk menikahkannya (menjadi wali nikah), sebagaimana ketentuan wali nikah yang ditentukan dalam Pasal 19 Kompilasi Hukum Islam :

a) Wali nikah dalam perkawinan merupakan rukun yang harus dipenuhi bagi calon mempelai wanita yang bertindak untuk menikahkannya.

b) Yang bertindak sebagai wali nikah ialah seorang laki-laki yang memenuhi syarat hukum Islam yakni muslim, akil dan baligh.

c) Ketentuan hukum yang sama sebagaimana ketentuan hukum terhadap anak luar nikah tersebut, sama halnya dengan status hukum semua anak yang lahir di luar pernikahan yang sah sebagaimana disebutkan di atas.

\section{Impilikasi Putusan MK Terhadap Anak Di luar Nikah}

Sebagaimana urian di atas putusan MK yang dibacakan tanggal 17 Februari 2012 mengenai status keperdataan anak di luar nikah tentu mempunyai implikasi hukum sebagai berikut: Pasal 43 ayat (1) Undang-Undang Nomor 1 Tahun 1974 tentang 
Perkawinan (Lembaran Negara Republik Indonesia Tahun 1974 Nomor 1, Tambahan Lembaran Negara Republik Indonesia Nomor 3019) yang menyatakan, "Anak yang dilahirkan di luar perkawinan hanya mempunyai hubungan perdata dengan ibunya dan keluarga ibunya", bertentangan dengan Undang-Undang Dasar Negara Republik Indonesia Tahun 1945 sepanjang dimaknai menghilangkan hubungan perdata dengan laki-laki yang dapat dibuktikan berdasarkan ilmu pengetahuan dan teknologi dan/atau alat bukti lain menurut hukum ternyata mempunyai hubungan darah sebagai ayahnya.

Pasal 43 ayat (1) Undang-undang Nomor 1 Tahun 1974 tentang Perkawinan (Lembaran Negara Republik Indonesia Tahun 1974 Nomor 1, Tambahan Lembaran Negara Republik Indonesia Nomor 3019) yang menyatakan, "Anak yang dilahirkan di luar perkawinan hanya mempunyai hubungan perdata dengan ibunya dan keluarga ibunya" tidak memiliki kekuatan hukum mengikat sepanjang dimaknai menghilangkan hubungan perdata dengan laki-laki yang dapat dibuktikan berdasarkan ilmu pengetahuan dan teknologi dan/atau alat bukti lain menurut hukum ternyata mempunyai hubungan darah sebagai ayahnya, sehingga ayat tersebut harus dibaca, "Anak yang dilahirkan di luar perkawinan mempunyai hubungan perdata dengan ibunya dan keluarga ibunya serta dengan lakilaki sebagai ayahnya yang dapat dibuktikan berdasarkan ilmu pengetahuan dan teknologi dan/atau alat bukti lain menurut hukum mempunyai hubungan darah, termasuk hubungan perdata dengan keluarga ayahnya”.

Putusan MK tersebut tentu akan berakibat pada perombakan hukum keluarga di Indonesia secara signifikan. Hukum positif selama ini menempatkan status hukum anak di luar nikah berbeda dengan anak sah. Anak di luar nikah diperlakukan secara berbeda karena hanya memiliki hubungan perdata dengan ibunya dan keluarga ibunya, yang berarti tidak memiliki hubungan perdata dengan ayah maupun keluarga ayahnya.

Perubahan status hak keperdataan anak di luar nikah menimbulkan beberapa akibat hukum. Pertama, kewajiban alimentasi bagi laki-laki yang dapat dibuktikan memiliki hubungan darah sebagai ayah dari anak luar kawin. Seorang 
ayah biologis sudah tidak bisa mengelak lagi atas kewajiban hukum untuk memelihara dan mendidik anak dengan alasan ketiadaan ikatan perkawinan yang sah dengan ibunya. Ayah harus memenuhi kebutuhan hidup dan pendidikan anak tersebut meskipun ia tidak terikat perkawinan dengan ibunya, atau bahkan sang ayah terikat perkawinan dengan orang lain.

Penghapusan perlakuan diskriminatif terhadap anak luar kawin tentu akan memberikan nilai kebaikan bagi masa depan anak. Kewajiban alimentasi yang selama ini hanya dipikul sendirian oleh seorang ibu kini berganti dipikul bersama seorang laki-laki sebagai ayah yang dapat dibuktikan memiliki hubungan darah dengan sang anak. Jika seorang ayah melalaikan kewajiban terhadap anaknya maka konsekuensi hukumnya ia dapat digugat ke pengadilan. Pendek kata, kebaikan masa depan anak di luar nikah menjadi lebih terjamin dan dilindungi oleh hukum.

Kedua, hak anak luar kawin atas harta warisan. Pengakuan anak di luar nikah memiliki hubungan keperdataan dengan ayah biologisnya maka tentu akan berakibat pada hak seorang anak mendapat harta warisan. Kedudukan anak di luar nikah menjadi setara dengan anak yang lahir sebagai akibat perkawinan yang sah.

\section{Kesimpulan}

Putusan MK mengenai status hak keperdataan anak di luar nikah merupakan suatu ijtihad revolusioner karena selama ini dipahami dalam konsep fiqh dan praktik hukum dalam peradilan, anak di luar nikah selama ini tidak memiliki hak saling mewaris dengan ayahnya karena ketiadaan nasab yang sah. Tentu dengan adanya putusan MK ini menjadikan anak di luar nikah sebagai pihak yang memiliki kedudukan hukum (persona in judicio) dalam perkara kewarisan di pengadilan serta berhak memperoleh harta warisan ayah biologisnya dengan keharusan mampu membuktikan adanya hubungan darah berdasarkan ilmu pengetahuan dan teknologi dan/atau alat bukti lain menurut hukum.

\section{Daftar Pustaka}


Afandi, Ali, Hukum Waris, Hukum Keluarga, Hukum Pembuktian, Jakarta: Rienek Cipta, 2000

Dahlan, Abdul Aziz, Ensklopedi Hukum Islam, Jakarta: PT. Ichtiar Baru Van Hoeve, 1999

Dampak Perkawinan di Bawah Tangan Bagi Perempuan. www.lbh-apik.or.id

Gaffar, Jenedjri M, Kedudukan, Tugas dan Peran Mahkamah Konstitusi Dalam Sistem Ketetanegaraan Republik Indonesia, Makalah, Surakarta, 17 Oktober 2009.

Inpres Nomor 1 Tahun 1991 Tentang Kompilasi Hukum Islam

Muhammad, Abdul Kadir, Humum Perdata di Indonesia, Bandung: PT. Citra Aditya Bakti, 1993

Satrio, J, Hukum Keluarga Tentang Kedudukan Anak Dalam Undang-undang, Bandung: PT. Citra Bhakti Aditya, 2000, halaman. 5

Soetojo, Prawirohamidjojo, R, Hukum Waris Kodifikasi, Surabaya: Airlangga University Press. 2000

Undang-undang Nomor 1 Tahun 1974 tentang Perkawinan 